\title{
Neisseria gonorrhoeae Measurement
}

National Cancer Institute

\section{Source}

National Cancer Institute. Neisseria gonorrhoeae Measurement. NCI Thesaurus. Code C161397.

The determination of the amount of Neisseria gonorrhoeae present in a sample. 